RESEARCH PAPER

\title{
From legitimate consumers to public relations pawns: the tobacco industry and young Australians
}

\section{S M Carter}

Tobacco Control 2003;12(Suppl III):iii71-iii78

\begin{abstract}
Objective: To document the Australian tobacco industry's activities regarding youth smoking to support tobacco control.

Method: 492 industry documents from primary and secondary websites were abstracted and analysed. Results: Australian legislation and rhetoric on youth and tobacco has changed dramatically over the last 50 years, from an unproblematic association of teenagers and smoking in the 1960s, through the industry's aggressive attacks and denials in the 1980s, to the 1990s, when industry became newly compliant with "societal expectations" and youth became a dominant bargaining issue in the industry's public relations strategy. The industry's current policy is to simultaneously blame others for underage smoking, frame the industry as socially responsible via voluntary marketing codes, youth access programmes, and school education, and market actively to young adults. Conclusions: The arbitrary distinction between 17 and 18 year olds is, particularly in Australia's dark market, a liability for tobacco control and an opportunity for the industry, which is attempting to claim the high moral ground traditionally occupied by tobacco control on the youth issue. The current review of Australia's Tobacco Advertising Prohibition Act of 1992 should prohibit all forms of industry communication targeting young people, including retail access and schools programmes and belowthe-line marketing. Tobacco control advocacy should highlight the industry's attempts to use the youth issue in its own favour while laying the blame elsewhere.
\end{abstract}

Correspondence to:

Public Health, Room 128A Building A27, University of Sydney NSW 2006,

Australia; carters@

health.usyd.edu.au

Y outh smoking is the focus of extensive research nationally and internationally, driven by a fundamental tenet of tobacco control: that most smokers become addicted as teenagers, before they are able to consent, and that the tobacco industry has worked to ensure that this continues. Recent research has shown that the most likely age for transition to regular smoking in Australia is 14 years, ${ }^{1}$ and that smoking by Australians aged under 18 supplies $\$ A 18.7$ million in profits to the tobacco industry, \$A18.7 million to retailers, and \$A87 million to the Australian government in taxation every year. ${ }^{2}$ International research has recorded the tobacco industry's explicit targeting of young people with market research, product design, and marketing strategies including advertising and pricing. ${ }^{3-6}$ In response to the problem, both tobacco control and the tobacco industry have created "youth smoking prevention" campaigns of varying effectiveness. The literature particularly criticises industry funded programmes..$^{7-12}$

Particularly of late, the traditional emphasis on youth in tobacco control policy has been challenged, authors suggesting that it plays into the industry's hands and diverts resources from more effective adult programmes. ${ }^{13}{ }^{14}$ Retail access programmes and school based education, in particular, have been criticised. Access programmes, which set legislated age limits for tobacco purchase and penalise retailers who do not comply, are considered likely to influence teen purchase rather than reduce smoking prevalence, ${ }^{15-17}$ and school based programmes are not well supported by the literature. ${ }^{15}{ }^{18-22}$

This work was funded by the Australian National Health and Medical Research Council (NHMRC) to investigate the actions of the industry in Australia. Given the central place of the youth issue in tobacco control, it was considered necessary for such a project to consider youth smoking in Australia. While the findings bear similarities to previous North American and European work, this research contributes to the body of existing literature by highlighting some activities that appear to have been unique to the Australian situation. Local manufacturers in Australia tend to distance themselves from accusations made against the international industry, increasing the need for research specific to Australia. ${ }^{23-25}$ In addition, most northern hemisphere research has focused on domestic (rather than international) brands and strategies, and has often used the documents of companies with a negligible presence in Australia, such as Lorillard and RJ Reynolds. Domestic northern hemisphere cigarette companies, operating in different legislative and constitutional environments, often have policies very different from those of their "international" arms, or the holding companies operating in other countries. Finally, much of the published research has focused on the industry's marketing to young people, and this paper additionally explicates the public relations aspects of the industry's youth programmes.*

\section{METHODS}

The source material for this paper came from primary and secondary online tobacco document collections. In addition to the manufacturers' websites, ${ }^{26}$ (US) Tobacco Institute website, $^{27}$ and Council for Tobacco Research website, ${ }^{28}$ material came from Tobacco Documents Online (Bliley, BC,

Abbreviations: AAA, US Action Against Access; ITL, "It's the Law"; NHMRC, Australian National Health and Medical Research Council; PMI, Philip Morris International; PML, Philip Morris (Australia) Limited; POS, point of sale; TIA, Tobacco Institute of Australia; WA, Western Australia; WRA, Worldwide Regulatory Affairs; YSP, youth smoking prevention

*For local advocates and lawyers a highly detailed analysis is available from http://tobacco.health.usyd.edu.au 
Health Canada and Guildford Miscellaneous collections), ${ }^{29}$ the Canadian Council for Tobacco Control site, ${ }^{30}$ the British Columbia Ministry of Health Services site, ${ }^{31}$ and the Center for Disease Control and Prevention Guildford site. ${ }^{32}$ The search string (pagewood or moorabbin or granville or australia or sydney or melbourne or brisbane or hobart or adelaide or perth or amatil or wills) has been used throughout the project to gather documents which related to the Australian market. Documents relating to youth smoking from this set were analysed. As relevant people, projects, and acronyms emerged they were further investigated on appropriate websites. In all, 492 documents were abstracted: abstracts are available from http://tobacco.health. usyd.edu.au/site/gateway/docs/index.htm.In addition, an archive of Australian tobacco retail magazines, held at the University of Sydney, and industry websites were examined for past and present industry youth policies and strategies. Detailed information about searching and analysis are available elsewhere. ${ }^{33}$

\section{RESULTS}

Australian legislation and rhetoric on youth and tobacco has changed dramatically over the course of the last 50 years, from an unproblematic association of teenagers and smoking in the 1950s and 1960s, through the industry's aggressive attacks and denials in the 1980s, to the 1990s, when industry became newly compliant with "societal expectations" and youth became the dominant bargaining issue in the industry's public relations strategy.

\section{TO 1990: FROM LEGITIMACY TO BATTLEGROUND}

In the 1950s and 1960s, cigarettes were advertised during children's television programmes ${ }^{34}$ and in teen magazines, ${ }^{35}$ and the industry openly encouraged tobacco retailers to pursue young smokers as a valuable future market. ${ }^{36}$ It was only in the 1970s, when Australian tobacco advertising was threatened by its perceived influence on children's uptake of smoking, that the industry began to attempt to dissociate tobacco advertising from children, consistently arguing that "all known research" showed that cigarette advertising had no influence. ${ }^{37}$ An Australian study published by the NHMRC in 1969 was used as evidence for this proposition for 20 years, despite the fact that it was not designed to examine any relation between smoking and advertising. ${ }^{38}$

\section{The aggressive $1980 \mathrm{~s}$}

In the 1980s, a particularly aggressive decade for the Australian industry, new arguments on youth emerged. The NHMRC study, which did show that peers and parents were important in children's smoking behaviour, was used to justify a shift towards blaming others for youth smoking, including parents, peers, siblings, retailers, government, tobacco control and youth themselves. ${ }^{39}$ In addition, the industry began to claim that youth smoking was merely "experimentation", that youth shouldn't smoke, and that smoking was a "mature" pastime appropriate only for adults. $^{40}$

In the 1980s the Tobacco Institute of Australia (TIA) had a respected and central position in the worldwide tobacco "family". ${ }^{41}$ In closed industry meetings the TIA argued dismissively that "children are the most over-protected of all consumers... [they] are being used as a major weapon in the anti-tobacco groups' fight to remove tobacco advertising and make smoking socially unacceptable-their aim is a smoke-free generation by 2000 , or to put you and your companies out of business", ${ }^{42}$ a position which informed and was informed by the rhetoric of Philip Morris International $(\mathrm{PMI}),{ }^{43}$ and INFOTAB. ${ }^{44}$
A key promoter of these arguments was Glen Smith, expatriot Australian and director of the "Children's Research Unit" in London, who had been recruited to the industry by Bryan Simpson, the TIA's inaugural director. Smith supplied two ironically conflicting services to the TIA and its international counterpart INFOTAB. The first was criticism on demand of tobacco control research. Smith's standard accusations were that public health studies had "methodological deficiencies reminiscent of a Swiss cheese ${ }^{\prime \prime 45}$ and were hopelessly naïve in their approach to children. ${ }^{46}{ }^{47}$ Secondly, as documented elsewhere, Smith conducted a large, ongoing study for the industry explicitly designed to show that advertising did not influence children's smoking. ${ }^{48} 49$ The study led to peer reviewed publications, monographs, and international presentations. The Australian segment of the "study" was completed in $1983 / 84$, fronted by a third party to cloak the industry's involvement. ${ }^{50-52}$

Smith was an "invaluable" witness and lobbyist in Australia, ${ }^{53}$ promoting his "study" to parliamentarians and the Australian media at a cost to the industry of $£ 1000$ a day. ${ }^{54}$ In 1988 Smith attempted to convince the TIA of the value of repeating the 1983/84 work, assuring them that it would provide the results, and thus the publicity, that they wanted ${ }^{55}$; but he was unsuccessful in meeting the TIA's precondition for funding - that he acquire the endorsement and preferably financial support of state governments. ${ }^{56-59}$ Despite the apparent end of Smith's financial relationship with the industry, they continued to quote his work until the late 1990s. Smith has continued his career as a youth research specialist servicing controversial industries.

\section{Regulatory battles in the $1980 \mathrm{~s}$}

The confrontational 1980s produced both wins and losses for the industry. Paul Hogan, iconic Australian actor, was removed from advertising for a major Australian youth brand, Winfield, through advocacy, ${ }^{60}$ and in the state of Victoria most tobacco marketing activities were banned by a far reaching bill achieved through meticulous tobacco control lobbying, $\dagger$ despite the industry's counter-efforts. ${ }^{61}$ However, the industry was more successful in other states, particularly Western Australia (WA) where extensive lobbying by the TIA and the manufacturers produced results ${ }^{62}$ including a major defeat of a bill which proposed banning tobacco advertising to protect children. This was seen as a major victory, and studied in overseas markets: the local industry attributed their success to a late and convincing performance by Smith in the WA parliament, ${ }^{63}$ political factors, and the focus and discipline of their campaign relative to that of the opposition. ${ }^{64}$

\section{Active industry targeting of young Australians in the 1970 s and 1980 s}

Consistent with activities overseas, and in contrast to their public position, many documents from the 1970s and 1980s show the tobacco industry's active commercial interest in Australian teens and young adults. WD \& HO Wills (Wills) and Philip Morris (Australia) Limited (PML) both studied 13 to 17 year old Australians in the 1970s for the purposes of increasing sales. ${ }^{65-67}$ Documents from the 1980s also contain explicit statements that young people are "the recruitment market" and research focused on these "starters." ${ }^{16-72}$ In the 1980s PMI also defined 18-25 year olds the world over as the company's "key target group", ${ }^{73}$ commissioning research to better understand differences between young adults from different countries. ${ }^{74}$

†Gray N. Interview. Personal communication to Chapman S, Carter S, Bryan-Jones K. Sydney:2002 Nov 29. 
An important event illustrating $\mathrm{PM}^{\prime}$ s worldwide targeting of young people is the failure of Marlboro, PM's global flagship brand, in the Australian market. Marlboro's failure was explicitly defined as a failure to market successfully to new smokers: Winfield, an "Aussie" brand, had attracted the bulk of Australian starters away from Marlboro from the mid 1970s. Other research in this volume explores the failure of Marlboro in more detail, defining it as a branding failure created by a lack of responsiveness to the unique characteristics of the Australian market. Marlboro's product, image, and pricing did not fit either of the two distinct Australian brand categories operating at the time. In addition, during the difficult economic times of the 1980s, Winfield's egalitarian, value-for-money, "Aussie" branding was more attractive to Australian youth than the premium priced American cultural imperialism of the Marlboro Cowboy. ${ }^{75}$ As a result, Marlboro's 31\% share of new smokers in 1972 had fallen to $1.5 \%$ by 1986 , in contrast to Winfield's $45 \%$ share. $^{71}$

The crisis was such that, for 10 years, PMI and Leo Burnett USA participated in and often controlled the attempts to find a solution, and the resulting memos clearly target Australian teenagers. It was agreed that "the key problem" was Marlboro's "lack of appeal to younger smokers,",76 and "rejection...by first time smokers". ${ }^{77}$ As Leo Burnett USA noted, nearly half of Australia's population was under 25 years old, 23\% under 15, and "given [their] predisposition to try/adopt new brands, this segment represents significant market opportunity". ${ }^{78}$ PMI worried that attempts since 1976 to "reintroduce vitality to the Marlboro brand among new smokers" had been so unsuccessful that Marlboro had "virtually no new smokers". Marlboro's branding did not "appeal to non-smokers with a future disposition to smoke when they are forming brand preferences". ${ }^{77}$ The proposed solution was to develop "advertising concepts that are capable of competing with Winfield during the critical 2-4 year period where brand selection is made by people who are disposed to smoke later" ${ }^{\prime 77}$ - that is, teenagers.

\section{THE 1990S TO THE PRESENT: FROM BATTLEGROUND TO "SOCIETAL ALIGNMENT"}

In the 1990s, as in other developed countries, the industry's youth strategy changed substantially. Instead of fighting, manufacturers began to seek "a license to operate" $e^{\prime 79}$ by

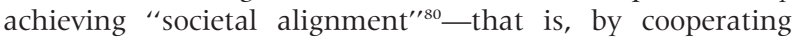
with perceived community standards. Youth programmes were the first pillar of the industry's new emphasis on reframing themselves as responsible, both globally and in Australian society. ${ }^{45} 8182$ As elsewhere, voluntary codes, retail access programmes, and school education programmes have been used to achieve this reframing. These have occurred in parallel with continuing targeting of "young adults" in marketing, ${ }^{7583}$ despite the manufacturers and the TIA insisting throughout the 1990s that youth should not smoke and that marketing was not targeted to and did not influence youth.

The majority of the relevant Australian documents available from the 1990s are from PML or its parent companies, and this is reflected in the following discussion.

\section{International codes of practice}

In 1991 the Philip Morris group began ongoing work on a PMI marketing code of practice. This involved PMI's presidents and vice presidents, senior counsel, regional presidents, field marketing staff, and senior management at PM Corporation. The code was intended to be used, particularly in lobbying, to gain a public relations advantage by promoting PMI as responsible towards youth, and to simultaneously protect PMI's ability to be "competitive and

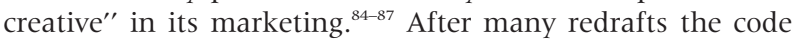

was distributed, including to PML, with memos insisting that it be implemented. ${ }^{88} 89$

Initially PMI planned to keep silent about the codes existence, storing it up as ammunition in case of a regulatory threat. ${ }^{90}{ }^{91}$ This softened over time, such that PMI shared it with other companies to encourage them to develop similar codes, $^{92}{ }^{93}$ and allowed PMI staff to refer to it in a general sense. Staff were not, however, to release it in full to other parties, as this would "[encourage] the outsider to police our activities and interpret the code when these responsibilities belong with the company itself". ${ }^{94}$ The public version of PMI's youth policy was instead encapsulated in a brochure, entitled "A global commitment to responsible marketing", for "legislators, journalists and decision makers from around the world"; the brochure intended to show that advertising did not cause youth smoking, and that PMI, with their marketing code, were the industry leaders on the issue and did not need to be regulated further. ${ }^{95} 96$

Simultaneously, in Australia, PML was developing a public relations management plan intended to regain PML's control of its operating environment in the face of massively declining social acceptability and wide opposition. This strategy was formulated by Matt Winokur, long time PM executive who at the time was director of corporate affairs for PMI and was also chief architect of the PMI voluntary marketing code. Along with more sordid lobbying activities, such as undermining the Ministerial Council on Drug Strategy by convincing state premiers that the council was usurping them, and creating "political capital" by getting inside Australia's "political machinery", PML's reputation was to be reconstructed in part by a "[programme] against youth smoking which goes beyond what is required." 829798 This was in response to research showing the potential value of the youth issue for the industry's PR programmes. ${ }^{99} 100$

The primary objective of the Australian industry youth campaign appears to have been the creation of "political capital" with politicians and third parties to enable the industry to counter political challenges. The youth issue has provided an excuse to approach the media, decision makers, and interest groups with "good news," as in the July 1998 self-congratulatory Report to federal and state politicians: Philip Morris addressing underage smoking in Australia. ${ }^{101}$ The industry's policy platform on youth also provides an immediate alternative to offer when challenged with more prohibitive regulation. ${ }^{102}$

\section{Access to cigarettes at retail in the 1990s}

PM was aware that retail access programmes had been found to be counterproductive, as evidenced by files from their worldwide regulatory affairs offices discussing conference proceedings where these findings were presented. ${ }^{103}$ Yet they continued aggressively pursuing access programmes when it suited the company's political agenda.

In response to US regulatory pressure in the mid 1990s, PM USA formed an "access taskforce" which created the US Action Against Access (AAA) programme. ${ }^{104}$ It simultaneously created a problem for PMI executives around the world, who were keen to avoid similar measures. Repeated shareholder efforts to force PM Corporation to implement AAA in developing country markets were deflected through the efforts of PM executives, mainly wielding the PMI marketing code. ${ }^{89}{ }^{91}{ }^{105-110}$ PML's assessment was that "it is only a matter of time before the Australian anti-smoking movement calls upon Philip Morris Australia to adopt all the measures of the AAA program...it will not be easy for us to distinguish ourselves from Philip Morris USA's adoption of the AAA program on the basis of difference in market, culture and practices." ${ }^{111}$ PML suggested that, if pressed, only voluntary codes would be entered in to, as it was too easy in 
"the hostile Australian environment" to "lose control over the progress and content" of legislation. ${ }^{111}$

A PMI Access Taskforce, including Australian representation, was formed in 1995, and along with Burson-Marstellar and its parent Young \& Rubicam, wrote a "strategy" which aimed to position PMI as an international leader by building the access issue as an international "brand", like a "global cigarette brand". ${ }^{112}$ It noted: "[this is] a key global program that is central to ensuring the long term growth of the company." 112 It was a classic public relations strategy, including development of arguments and allies, monitoring the opposition, and lobbying, ${ }^{112}$ all based on the fundamental principle that "PMI cannot be held reasonably responsible for ensuring that no minor smokes". ${ }^{113}$

The Australian industry had used access strategies since the successful 1983 battle against WA advertising bans. ${ }^{43}$ These early rudimentary signage systems evolved incrementally into the 1993 programme "It's the Law" (ITL). Similar to access programmes elsewhere, it was promoted by PML sales representatives and supported by an associated lobbying/ media campaign. ${ }^{114}$ Since then it has been regularly relaunched and subtly re-badged, promoted to tens of thousands of retailers, used to forge links with third parties such as retailer associations, promoted to politicians, and via general, retail, and culturally specific media, and has been expanded into helplines, campaign kits, and training videos. ${ }^{101}$ In its current incarnation, it includes point of sale (POS) signage and billboards, jointly funded by the three manufacturers, providing a rare opportunity for "Australian Tobacco Companies" to raise their profile with the public in a highly restricted marketing environment. ${ }^{\text {33a }} 115116$

ITL also provides the industry with additional "clout" with their "natural constituency" - that is, their retail and wholesale customers. ${ }^{117}$ Other research in this volume has demonstrated the heightened power and importance of the retailer in Australia's dark marketing environment. ${ }^{83 a}$ The industry has, on occasion, remonstrated with retailers over their role in underage cigarette sales. ${ }^{118}$ However, they have more often been concerned about the intrusions of access policies on retailers, distanced themselves from any policing role, and reassured retailers that the industry understands that they act responsibly and has provided ITL to assist them. ${ }^{111} 119$

\section{Youth school programmes in the 1990s}

The Australian industry's ongoing youth programme also features school based education, as in other markets. In Australia it has been spearheaded by a conservative "educationalist", Dr Kevin Donnelly. He has strong connections to the conservative Liberal Party and to the private school sector, and frequently editorialises on educational policy as an "independent consultant". His consulting group, Education Strategies, developed an Australian schools programme based on a South American programme "Yo-Tengo" ("I Have"). "Intensive [Australian] research among practicing teachers, and actual classroom application" resulted in an amended programme, launched in 1998, entitled "I've Got the Power". ${ }^{120}$ It was designed for secondary schools in Australia and New Zealand, and subsequently expanded to an indigenous and a primary school programme. As with other similar programmes, tobacco was not prominent, and was presented in the context of decision making, not health: in PML's words, the programme "assist[ed] children to make responsible lifestyle choices with regard to a range of things that adults believe children should not do". ${ }^{120}$

Many of the available documents regarding "I've Got the Power" are correspondence between PML and PMI regarding the acknowledgement of PML's funding of the programme. Although PMI policy was to always attribute PM's backing of such programmes, PML warned that in the hostile Australian environment, this would result in widespread rejection of the programme. ${ }^{120-123}$ The appropriate response was decided by Worldwide Regulatory Affairs (WRA). Firstly, PML should "get a letter from the government along the following lines: We are aware that PM is supporting Education Strategies in the development of the "I've got the power" program, and we applaud your efforts to help underwrite an education program to help youth make smart choices avoid peer pressure etc. We do not believe it would be effective for a program such as "I've Got the Power" to be used for public relations or corporate identification purposes and we would therefore ask that you refrain from putting PM's name on the materials." 124 "Government officials" should then be advised of PML's investment, via a letter drafted by WRA and the aforementioned PR document Philip Morris Addressing Underage Smoking in Australia. ${ }^{125-129}$ Then the kits could be printed without PML's funding being attributed.

Although Donnelly's association with PML continues, attempts to garner publicity for the programme in Australia are dogged by controversy, to which he consistently responds that "I've got the power" is not about smoking and was developed independent of Philip Morris. ${ }^{130-135}$

\section{Late 1990s: "new day", new cooperation}

Geoff Bible's February 1998 "new day" speech before the US Senate Commerce Committee, which committed to minimum age laws, youth access programmes, anti-smoking education programmes, product labels against "underage" usage, and limits on cigarette marketing, ${ }^{136} 137$ started a new phase of "youth" activity at PMI. ${ }^{138} 139$ This activity again took the basic position that marketing freedoms must be protected. PMI personnel argued "we must be seen to be acting responsibly and not [be seen to be] to blame [for the fact] that kids do smoke. We do not have a role in why kids smoke, and we cannot control kids from doing so."139 140 A new "Global Commitment in Support of Youth Smoking Prevention" and new processes, guidelines and meetings resulted, making "youth smoking prevention" (YSP) an ongoing international project which included Australia. ${ }^{80}{ }^{141-146}$

These activities created a problem of which PMI personnel were keenly aware: that the company could create rules for itself more stringent than those of its competitors, particularly given that they believed that "BAT and local competitors are not going to play this game: they do not see the world this way". ${ }^{142} 147148$ In 1998 PMI went into negotiations with RJ Reynolds Tobacco International and BAT, after which they were "hopeful that we will be able to implement a greatly expanded joint international industry youth access and marketing code to which all major industry participants will voluntarily adhere". ${ }^{149}$ PMI created two lists of possible concessions in preparation for the meeting: those PMI would make unilaterally versus those which would only be made if forced or mutual-that is, those which they considered potentially damaging to their competitiveness. ${ }^{150}$ The result was a set of "International Tobacco Products Marketing Standards" signed by the parents of both PML and British American Tobacco Australia, along with other companies. ${ }^{151}$

On their corporate websites, PMI presents these standards as a necessary control of their competitors; BAT presents them as exciting progress in the area of YSP. In contrast, Credit Suisse Equity Research/First Boston advised on the release of the standards: "we... believe that the multinationals' strategy is proactive and is a way to improve their image... [possibly to] counter a number of proposals that the WHO has been working on...in many countries the existing laws or industry codes are already more restrictive than [these] standards...we believe the [modest savings resulting from changed marketing practices] will be redirected into other types of marketing promotions i.e. point of sale 
activity." ${ }^{152}$ PM Corporation (now Altria), BATA, and BAT continue to promote their responsible investment in YSP in their "social reporting" and at annual general meetings. ${ }^{153-155}$

\section{Shifting the blame}

In parallel with these cooperative social programmes, the industry maintains a strategy of blaming others for youth smoking at every opportunity. When Philip Morris Corporate Affairs discussed "Youth: a corporate strategy that applies to food, tobacco and beer" at a world conference, it noted "Key issue: individual responsibility. Put the onus on kids, parents, teachers, retailers, legislators/regulators". ${ }^{156}$ Many documents from the 1990s, as in the 1980s, blame "parents and peers" for youth smoking, and this appears to be a central strategy for Altria. In 2002, Geoff Bible, then CEO of PM Corporation, told shareholders that "most young people don't buy cigarettes, they get them from loose packs left lying around by adults", urging adults to be "more careful", 157 and new mass media YSP programmes were planned to focus on parents' responsibilities. ${ }^{158}$ Young smokers themselves are also blamed, as evidenced by PML's 1998 proposal to Australian government that they work with industry to "investigate the feasibility of making it an offence for underage youth to purchase tobacco". ${ }^{101}$

\section{CONCLUSIONS}

This paper has documented the development of youth strategy within the tobacco industry in Australia and in the parent companies of Australian manufacturers. It has shown that the Australian tobacco industry, like the industry elsewhere, has targeted young people in its research and marketing, although the changing acceptability of that activity over time has forced the industry's public position to evolve. From unproblematic advertising to children in the 1950 s and 1960s, to aggressive denials in the 1980s, to the "societal alignment" strategies of the 1990s, the youth issue has become increasingly central to the Australian industry's agenda over 50 years.

The industry's continuing active engagement in the development of voluntary codes, ITL, and "I've got the power", along with its "social reporting" demonstrates an intention to continue benefiting from promotion of its "responsibility" towards teenagers, particularly with government and retailers. Manufacturer's internal documents show a parallel intention to shift the blame for youth smoking onto alternative scapegoats, particularly young people and their addicted smoking parents, while distancing the industry from taking responsibility.

There is no doubt that Australian cigarette manufacturers have marketed deliberately to teenagers. However, as the public relations imperative has grown, overt evidence of the industry marketing to youth under 18 has faded. Instead, as seen earlier from PMI's 1989 meeting, the 18-25 year age group has been defined as the industry's "key target group". Other work in this volume has documented the guerrilla marketing strategies subsequently used by the industry to attract young adults in Australia. ${ }^{83}$ This is further reinforced by BATA's 2002 Social Report. This report was supposedly a responsive exercise based on "stakeholder research". However, despite BATA's "stakeholders" defining "youth" as "people under the age of 25 " during the research process, the report committed only to "reducing the supply of tobacco products to people under 18 years of age". ${ }^{155}$

The industry has, effectively, learned from the strategies of tobacco control. Their current position resonates with the aforementioned 1984 speech by the CEO of the TIA, which claimed that "children are being used as a major weapon in the anti-tobacco groups' fight to remove tobacco advertising and make smoking socially unacceptable." ${ }^{\prime 2}$ The 21 st century

\section{What this paper adds}

Youth smoking is a central and contested issue in the tobacco control literature. Previous research has shown that the industry has explicitly marketed its products to young people, and has noted the public relations value of industry funded "youth smoking prevention" programmes.

This paper details the Australian industry's targeting of young people, its use of youth smoking prevention for public relations purposes, and its continuing policy of blaming others for youth smoking. It argues the need to prohibit both marketing and youth smoking prevention funded by the industry, and reframe the youth issue in tobacco control debates.

reality is, in fact, that children are being used as a major weapon in the tobacco industry's fight to protect the tobacco market and make smoking more socially acceptable. It could, in fact, be argued that tobacco control has unwittingly played into the industry's hands, providing them with a failsafe source of legitimacy. They are now in a position to argue, as Bible did in 1995, that "we stand ready to work with anyone who truly wants to address this issue", ${ }^{112}$ implying that anyone who is caring, responsible and serious about youth smoking, like Altria, will cooperate with the company's agenda. If the industry can overcome community cynicism, this strategy has the potential to give them a much needed upper hand.

The fundamental flaw in the industry's logic is the arbitrariness of the distinction between "youth" and "adult" marketing targets. It is commonly observed that teens tend to mimic those just older than themselves and strive to establish themselves as independent, and that the industry's youth smoking programmes play to those characteristics by emphasising the "forbidden fruit" aspects of smoking. As years of dedicated research, media circulation demographics, and even common sense dictates, it is impossible to quarantine those under 18 years of age from aspiring to, or participating in, activities designed for those over 18. The notion that aggressively marketing cigarettes to an 18 year old is somehow ethical, because it is legal, is an equally suspect proposition. This false distinction is the biggest challenge facing activism on the youth smoking issue in Australia and elsewhere, requiring deft handing and complete reframing. Traditional accusations that the industry markets to children are less powerful now, particularly in the Australian market where any form of promotion is illegal. The key frame through which tobacco control can target the industry on youth is now their efforts to reframe the debates in their own favour while laying the blame elsewhere.

The Tobacco Advertising Prohibition Act 1992, which provides Australia with its strong marketing restrictions, is under review at the time of writing this paper. The review provides an opportunity to widen the definition of "advertising" to include tobacco industry communications of any kind, including below the line advertising, retail access campaigns, and schools programmes. This study suggests that such a move is justified in light of the evidence on the industry's youth programmes in Australia. Such policies could reorient tobacco control away from arbitrary age distinctions that serve the industry's marketing aims, and toward effective tobacco control for the benefit of the entire Australian population.

\section{ACKNOWLEDGEMENTS}

Thanks are due to Simon Chapman and reviewers for their comments, and to Fiona Byrne for her superlative information management. The research reported in this paper was supported by 
grants from the National Health and Medical Research Council (2001-2003 \#153857) and the US National Institutes of Health (2001-2005 \# R01 CA87110-01Al).

\section{REFERENCES}

White V, Scollo M. How many children take up smoking each year in Australia? Aust N Z J Public Health 2003;27:359-60

2 White V, Scollo M. What are underage smokers worth to Australian toabcco companies? Aust N Z J Public Health 2003;27:360-61.

3 ASH UK. Danger! PR in the playground. London: ASH UK and the Cancer Research Campaign, 2000. http://www.ash.org.uk/html/advspo/html/ prmenu.html. (Accessed 22 Jul 2003)

4 Cummings KM, Morley CP, Horan JK, et al. Marketing to America's youth: evidence from corporate documents. Tobacco Control 2002;11/suppl I):i5-17

5 Pollay RW. Targeting youth and concerned smokers: evidence from Canadian tobacco industry documents. Tobacco Control 2000:9:136-47.

6 Perry CL. The tobacco industry and underage youth smoking: tobacco industry documents from the Minnesota litigation. Arch Pediatr Adolesc Med 1999; 153:935-41

7 Farrelly MC, Healton CG, Davis KC, et al. Getting to the truth: evaluating national tobacco countermarketing campaigns. Am J Public Health 2002:92:901-7.

8 Biener L. Anti-tobacco advertisements by Massachusetts and Philip Morris: what teenagers think. Tobacco Control 2002;11(suppl II):ii43-6.

9 Sly DF, Heald GR, Ray S. The Florida "truth" anti-tobacco media evaluation: design, first year results, and implications for planning future state media evaluations. Tobacco Control 2001;10:9-15.

10 Zucker D, Hopkins RS, Sly DF, et al. Florida's "truth" campaign: a countermarketing, anti-tobacco media campaign. Journal of Public Health Management \& Practice 2000;6:1-6.

11 Riester T, Linton M. Designing an effective counteradvertising campaign-Arizona. Cancer 1998;83:2746-51

12 Miller A. Designing an effective counteradvertising campaign Massachusetts. Cancer 1998:83:2742-5.

13 Bayer R, Kiesig V. Is child-centered tobacco prevention a trap? Am J Public Health 2003;93:369-70.

14 Hill D. Why we should tackle adult smoking first. Tobacco Control 1999:8:333-5.

15 Landman A, Ling PM, Glantz SA. Tobacco industry youth smoking prevention programs: protecting the industry and hurting tobacco control. Am J Public Health 2002;92:917-30.

16 Ling PM, Landman A, Glantz SA. It is time to abandon youth access programs. Tobacco Control 2001;11:2-6.

17 Stead LF, Lancaster T. Interventions for preventing tobacco sales to minors. Cochrane Database Syst Rev 2002: Accessed via Ovid/Cochrane Database Syst Rev. 22 Jul 2003.

18 US Department of Health and Human Services. Reducing tobacco use: a report of the Surgeon General. Atlanta, Georgia: US Department of Health and Human Services, Centers for Disease Control and Prevention, National Center for Chronic Disease Control and Prevention, Office on Smoking and Health, 2000.

19 Peterson JA, Kealey K, Mann S, et al. Hutchison smoking prevention project: long term randomised trial in school based tobacco use prevention-results on smoking. J Natl Cancer Inst 2000;92:1979-91.

20 Jha P, Chaloupka FJ. Curbing the epidemic: governments and the economics of tobacco control. Washington DC: World Bank, 1999. http:// www.globalink.org/tobacco/wb/ (Accessed 27 Sep 2001)

21 Charlton A, Blair V. Absence from school related to children's and parental smoking habits. BMJ 1989;298:90-2.

22 Nutbeam D, Macaskill P, Smith C, et al. Evaluation of two school smoking education programmes under normal classroom conditions. BMJ 1993:306:102-7.

23 Harris T. US smokes not like ours. The Weekend Australian (Sydney) 12 Jul 1997:7.

24 WD \& HO Wills. WD. \& HO Wills Holdings-Chairmans Address. 17 Apr 1997. Philip Morris. Bates No. 2072527522/7525. http:// legacy. library.ucsf.edu/tid/vtc42c00

25 Lipari K. Rothmans warns on profit. 12 Jul 1997. Philip Morris. Bates No. 2065329380. http://legacy.library.ucsf.edu/tid/qdp63c00

26 Tobacco manufacturers' document websites. http://www.pmdocs.combin/rsasearch.asp; http://www.bw.aalatg.com/public.asp; http:// www.lorillarddocs.com/cgi-bin/rsasearch.asp; http://www.rirtdocs.com/ rirtdocs/index.wmt?tab $=$ home

27 Tobacco Institute document website. http://www.tobaccoinstitute.com/cgibin/Rsasearch.asp

28 Council for Tobacco Research document website. http://www.ctr-usa.org/ ctr/index.wmt?tab = home

29 Tobacco Documents Online. Smokescreen Corporation. http:// tobaccodocuments.org/

30 Canadian Council for Tobacco Control tobacco documents site. http:// www.ncth.ca/Guildford.nsf

31 British Columbia Ministry of Health Services tobacco documents site. http://www moh. hnet.bc.ca/cgi-bin/guildford search.cgi

32 Center for Disease Control and Prevention Guildford tobacco documents site. http://www.cdc.gov/tobacco/industrydocs/index.htm

33 Chapman S, Byrne F, Carter SM. "Australia is one of the darkest markets in the world": the global importance of Australian tobacco control. Tobacco Control 2003;12(suppl III):iii 1-3.
34 US Public Health Service. Smoking and health programs around the world. 1970 Jun. R.J. Reynolds. Bates No. 500891895/1910. http:// legacy.library.ucsf.edu/tid/snw59d00

35 How important is the teenage market? Tobacco Journal (Victoria) 1964;33(5/6):21

36 Ways to encourage the young smoker. Tobacco Trade Journal (Queensland) 1954;13(5):11,24.

37 Philip Morris. Some comments on a report by the Senate Standing Committee on Social Welfare "Drug Problems in Australia". Feb 1978 Philip Morris. Bates No. 2015016980/6997. http:// legacy.library.ucsf.edu/tid/xib44e00

38 National Health and Medical Research Council. Report of a survey into the smoking habits and attitudes of Australian schoolchildren by the adhoc smoking survey sub-committee. Canberra: National Health and Medical Research Council, 1969

39 Tobacco Institute of Australia. Casebook arguments. May 1986. Philip Morris. Bates No. 2501456347/6356. http://legacy.library.ucsf.edu/tid/ clu22e00

40 Tobacco Institute of Australia. The tobacco industry and juvenile smoking Oct 1983. Philip Morris. Bates No. 2504203705/3717. http:// legacy.library.ucsf.edu/tid/vkj29e00

41 Carter SM. Cooperation and control: the Tobacco Institute of Australia. Tobacco Control 2003;12(suppl III):iii54-60.

42 Dollisson J. The politicisation of the child-a tool of the anti's. 11 Oct 1984 R.J. Reynolds. Bates No. 503887595/7604. http://legacy.library.ucsf.edu/ $\mathrm{tid} / \mathrm{ixu} 75 \mathrm{~d} 00$

43 Whist A. Tobacco issue briefs. Apr 1985. Philip Morris. Bates No. 2501444256/4272. http://legacy library ucsf.edu/tid/gor22e00

44 INFOTAB. Cigarette advertising and consumption of cigarettes by children: is there really evidence of a causal relationship? Mar 1990. R.J. Reynolds. Bates No. 51 1992397/2403. http://legacy.library.ucsf.edu/tid/ysi43d00

45 INFOTAB. INFOTAB International Workshop, Brussels, Belgium, October 13-16, 1986. 16 Oct 1986.Philip Morris.Bates No. 2501446636/7080. http://legacy.library.ucsf.edu/tid/alr02a00

46 Smith G. Advertising and children: a paper given to the European group of coordinators, Brussels, 1 st February 1984. 1 Feb 1984. R.J. Reynolds. Bates No. 502487479/7491. http://legacy.library.ucsf.edu/tid/mgd88d00

47 Smith G, Sweeney E. Children and television: an overview. 1984. Tobacco Institute. Bates No. TIMN0321 287/1337. http://legacy.library.ucsf.edu/ tid/edt52f00

48 Hirschhorn N. Tobacco industry documents in the Minnesota Depository: implications for global tobacco control. Briefing paper number one: tobacco industry campaign against advertising bans in the 1980s, Globalink 1998. Last updated: Oct 1998. http://www.globalink.org/tobacco/docs/ secretdocs/minnesota.shtml (Accessed 1 Jul 2002)

49 Hirschhorn N. Tobacco industry documents in the Minnesota Depository: implications for global tobacco control. Briefing paper number two: scientific review of data sponsored by the tobacco industry campaign against advertising bans in the 1980s. Globalink 1998. Last updated: Sep 1998. http://www.globalink.org/tobacco/docs/secretdocs/minnesota.shtml (Accessed 1 Jul 2002)

50 Duffin AH. Proposed Glen Smith research. 11 Dec 1985. Tobacco Institute. Bates No. TIMN0312842. http://legacy.library.ucsf.edu/tid/gxm62f00

51 INFOTAB. INFOTAB Board of Directors Meeting, Brussels. 4 Apr 1984. Philip Morris. Bates No. 2024970720/0804. http:// legacy.library.ucsf.edu/tid/bds02a00

52 Batten K. PMA weekly highlights. 16 Mar 1984. Philip Morris. Bates No. 2023265799/5802. http://legacy.library.ucsf.edu/tid/yku24e00

53 Pottorff M. INFOTAB workshop, Brussels, October 8-11, 1984. 18 Oct 1984. Philip Morris. Bates No. 2023272778/2780. http:// legacy.library.ucsf.edu/tid//zv36e00

54 Children's Research Unit. Case for international results merchandising. 1989. Philip Morris. Bates No. 2501457079/7080. http:// legacy.library.ucsf.edu/tid/oai22e00

55 Smith G. [Letter to Dr Blair Hunt, Chief Executive of the Tobacco Institute of Australia]. 16 Sep 1988. Philip Morris. Bates No. 2501040067. http:// legacy.library.ucsf.edu/tid/lvy32e00

56 Hunt BL. CRU research into children \& advertising. 5 Oct 1988. Philip Morris. Bates No. 2501457108. http://legacy.library.ucsf.edu/tid/ $\mathrm{ntj} 49 \mathrm{e} 00$

57 Ross JP. [Letter to Glen Smith]. Oct 1988. Philip Morris. Bates No. 2501457111. http://legacy.library.ucsf.edu/tid/cti49e00

58 Homel P. [Letter to Glen Smith]. 12 Oct 1988. Philip Morris. Bates No. 25014571 10. http://legacy.library.ucsf.edu/tid/btj49e00

59 Daube MM. [Letter to Glen Smith]. 27 Oct 1988. Philip Morris. Bates No. 2501457109. http://legacy.library.ucsf.edu/tid/atj49e00

60 Chapman S. A David and Goliath story: tobacco advertising in Australia. BMJ 1980;281:1187-90.

61 INFOTAB. Infotopics: summaries of public information, Vol. 6, no. 11. 30 Nov 1987. Tobacco Institute. Bates No. TI12260816/0871. http:// legacy.library.ucsf.edu/tid/ayl40c00

62 Philip Morris International. Corporate Affairs report. 1980. Philip Morris Bates No. 2048129267/9296. http://legacy.library.ucsf.edu/tid/ rbr42d00

63 Musk AW, Shean R, Woodward S. Legislation for smoking control in Western Australia. BMJ 1985;290:1562-5.

64 Whist A. Final appraisal of the public campaign to defend marketing rights in Western Australia. 13 Feb1984. Philip Morris. Bates No. 2023272348/ 2351. http://legacy.library.ucsf.edu/tid/hnt24e00 
65 The Australian Tobacco Industry. The cigarette health controversy. 1976. R.J. Reynolds. Bates No. 502814751/4756. http://legacy.library.ucsf.edu/ $\mathrm{tid} / \mathrm{ty}+31 \mathrm{~d} 00$

66 Phillip Morris Limited Australia, Lorillard Asia Ltd. 1977 Kent marketing plan. 1977. Brown \& Williamson. Bates No. 682111196/1221. http:// legacy.library.ucsf.edu/tid/eix70f00

67 Negrine N. Kim Diagnostic Research Melbourne. WD \& HO Wills. 1 Dec 1976. Brown \& Williamson. Bates No. 779105963/5969. http:// legacy.library.ucsf.edu/tid/wum 11 foo

68 BATCo. Document re: Australian market. 1986. British American Tobacco. Bates No. 102699796/9797. http://tobaccodocuments.org/ health canada/10269982.html (Accessed 13 Mar 2003)

69 WD \& HO Wills (Australia) Limited. Value for money marketing in Australia. 1983. Brown \& Williamson. Bates No. 621707306/7370. http:// legacy.library.ucsf.edu/tid/fid70f00

70 No author. Australian cigarette market. 1984. Brown \& Williamson. Bates No. 675147695/7710. http://legacy.library.ucsf.edu/tid/ryk73fo0

71 Philip Morris (Australia) Limited. [Competitive intelligence information on Winfield produced by Philip Morris]. Nov 1986. Philip Morris. Bates No. 2500131194/1213. http://legacy.library.ucsf.edu/tid/tpc42e00

72 Butson E. NPD. 23 Jun 1986. Philip Morris. Bates No. 2500001706. http:// legacy.library.ucsf.edu/tid/pvi42e00

73 Philip Morris International. Draft agenda PMI marketing meeting. 1 May 1989. Philip Morris. Bates No. 25001 14197/4202. http:// legacy. library.ucsf.edu/tid/bgl19e00

74 Leo Burnett Agency. International target trends presentation. 11 Aug 1989. Philip Morris. Bates No. 2500137354/7455. http:// legacy.library.ucsf.edu/tid/lcd42e00

75 Carter SM. The Australian cigarette brand as product, person, and symbol. Tobacco Control 2003;12(suppl III):iii79-86.

76 Zelkowitz D. Australia. 29 May 1984. Philip Morris. Bates No. 2023265684/5686. http://legacy.library.ucsf.edu/tid/bmr98e00

77 Philip Morris International. Marlboro advertising brief for Leo Burnett (re: Australia). 23 Jul 1984. Philip Morris. Bates No. 2023265680/5683. http://legacy.library.ucsf.edu/tid/amr98e00

78 Leo Burnett Agency. Exploratory Marlboro Strategic Research Australia. 10 Feb 1989. Philip Morris. Bates No. 2504057280/7368. http:// legacy.library.ucsf.edu/tid/sot19e00

79 British American Tobacco Australasia. The challenge of change [CD Rom]. Sydney: British American Tobacco Australasia, 2001

80 Kush AO. Youth Smoking Prevention Meeting, July 27-28, 1999, Lausanne. 13 Jul 1999. Philip Morris. Bates No. 2070045517D/5521. http:// legacy.library.ucsf.edu/tid/sxa38d00

81 Mallinson S. Supply of tobacco products \& promotional items to juveniles. 17 Feb 1988. Philip Morris. Bates No. 2504076001. http:// legacy.library.ucsf.edu/tid/hbh29e00

82 Winokur M. [Public affairs management plan for Australia]. Jun 1993. Philip Morris. Bates No. 2504200125/0143. http://legacy.library.ucsf.edu/tid/ ghc87e00

83 Carter SM. Going below the line: creating transportable brands for Australia's dark market. Tobacco Control 2003;12(suppl III):iii87-94.

83a Carter SM. New frontier, new power: the retail environment in Australia's dark market. Tobacco Control 2003;12(suppl III):iii95-101.

84 Buzzi A. PMI Marketing Code. Jun 1991. Philip Morris. Bates No. 2500050364. http://legacy.library.ucsf.edu/tid/fcg87e00

85 Buzzi A. Philip Morris International Marketing Code. Jun 1991. Philip Morris. Bates No. 2500050365. http://legacy.library.ucsf.edu/tid/ gcg87e00

86 Pollak L. Marketing Code. 8 Aug 1991. Philip Morris. Bates No. 2500052592. http://legacy.library.ucsf.edu/tid/jsf87e00

87 Nelson JR. PMI Marketing Code. 4 Sep 1991. Philip Morris. Bates No. 2500052577. http://legacy.library.ucsf.edu/tid/gsf87e00

88 Winokur M. PMI Marketing Code. 21 Sep 1992. Philip Morris. Bates No. 202331 1714. http://legacy.library.ucsf.edu/tid/cba98e00

89 Winokur M. Marketing code of practice. 15 Mar 1993. Philip Morris. Bates No. 250005271 1. http://legacy.library.ucsf.edu/tid/psf87e00

90 Pollak L. Marketing Code. 15 Sep 1992. Philip Morris. Bates No. 2500050515. http://legacy.library.ucsf.edu/tid/jcg87e00

91 Winokur M. PMI voluntary marketing code status. 19 Feb 1993. Philip Morris. Bates No. 2022989144. http://legacy.library.ucsf.edu/tid/ rac15e00

92 Winokur M. PMI Marketing Code Communications Plan. 25 Mar 1993 Philip Morris. Bates No. 2045680295/0296. http:// legacy.library.ucsf.edu/tid/ini87e00

93 Winokur M. PMI Marketing Code. 3 Jun 1993. Philip Morris. Bates No. 2501287635. http://legacy.library.ucsf.edu/tid/tuj49e00

94 Pollak L. Marketing code. 29 Mar 1993. Philip Morris. Bates No. 2500122231. http://legacy.library.ucsf.edu/tid/rae58d00

95 Philip Morris International. Notes for international youth brochure. 1992. Philip Morris. Bates No. 2022810713/0714. http:// legacy.library.ucsf.edu/tid/tzł35e00

96 Philip Morris International. A global commitment to responsible marketing. Aug 1994. Philip Morris. Bates No. 2501008958/8963. http:// legacy.library.ucsf.edu/tid/koj22e00

97 Winokur M. Phase Two: Changing the operating environment. 1993. Philip Morris. Bates No. 2504200155/0156. http://legacy.library.ucsf.edu/tid/ kmj29e00

98 Winokur MN. Phase two elaboration. Apr 1993. Philip Morris. Bates No. 2504200157/0160. http://legacy.library.ucsf.edu/tid//mj29e00
99 Wirthlin Group. Australian corporate image study: general public and opinion leaders. Apr 1993. Philip Morris. Bates No. 2025837529/7579 http://legacy.library.ucsf.edu/tid/uny83e00

100 Tobacco Institute of Australia. Draft project plan for ETS public smoking and credibility. 28 Jul 1993. Philip Morris. Bates No. 2504079120/9125. http://legacy.library.ucsf.edu/tid/ipk02a00

101 Philip Morris. Addressing underage smoking in Australia: report to Federal \& State politicians. Jul 1998. Philip Morris. Bates No. 2063552750/2769. http://legacy.library.ucsf.edu/tid/tna42d00

102 Brady B, Weedon D. Head to head: should tobacco be listed as a poison? 3 Aug 1995. Philip Morris. Bates No. 2065095594. http:// legacy.library.ucsf.edu/tid/ufl22d00

103 Han V. [Tobacco Control conference notes]. 1993. Philip Morris. Bates No. 2023922703/2801. http://legacy.library.ucsf.edu/tid/cif34e00.

104 Davidson DK. Selling sin. Westport, Conneticut: Quorum Books, 1996.

105 [Philip Morris Corporation shareholders]. Philip Morris Cigarette Marketing Practices in Developing Nations. Sep 1991. Philip Morris. Bates No. 2500052591. http://legacy.library.ucsf.edu/tid/rii19e00

106 Bartlett DT. [Compound document: includes letter from PM Corp to Sister Mary Lucey re: a shareholders proposal on youth smoking]. 26 Oct1992. Philip Morris. Bates No. 2045745672/5673. http:// legacy.library.ucsf.edu/tid/cot82e00

107 No author. Global Warning Philip Morris [shareholder proposal]. 1 Jan 1995. Philip Morris. Bates No. 2024152576. http:// legacy.library.ucsf.edu/tid/kym42e00

108 Burrell WG. Shareholder's proposal. 26 Nov 1996. Philip Morris. Bates No. 2500076258. http://legacy.library.ucsf.edu/tid/kae58d00

109 Philip Morris. Philip Morris holds 1998 annual meeting: Chairman criticizes Senate Tobacco Bill, reaffirms commitments to reducing underage use of tobacco products and to building shareholder value. $30 \mathrm{Apr}$ 1998. Philip Morris. Bates No. 2501765081/5084. http://legacy.library.ucsf.edu/tid/ iev28d00

110 Philip Morris International. Protecting youth from smoking in developing countries. 3 Dec 1996. Philip Morris. Bates No. 2500076256. http:// legacy.library.ucsf.edu/tid/ydl19e00

111 Staunton D, Windholz EL. Youth Access Taskforce Action Against Access (AAA). 28 Jul 1995. Philip Morris. Bates No. 2504080744/0748. http:// legacy.library.ucsf.edu/tid/mhc87e00

112 Young \& Rubicam, Burson Marstellar. Access: Philip Morris International. 13 Sep 1995. Philip Morris. Bates No. 2500076311/6330. http:// legacy.library.ucsf.edu/tid/mdl19e00

113 Philip Morris International. [Philip Morris International Youth Access Taskforce document on 'Youth Smoking Issues']. Sep 1995. Philip Morris. Bates No. 2047832694/2701. http://legacy.library.ucsf.edu/tid/ arf75e00

114 Philip Morris (Australia) Limited. It's the law: it's illegal to sell cigarettes to persons underage: Philip Morris retailer campaign representatives kit. 23 Sep 1993. Philip Morris. Bates No. 2022810557/0561. http:// legacy.library.ucsf.edu/tid/bag35e00

115 British American Tobacco Australasia. British American Tobacco Australasia website. British American Tobacco Australasia 2002. http:// www. bata.com.au (Accessed 2 Dec 2002).

116 Philip Morris International. Philip Morris International website. Philip Morris International 2002. http://www. philipmorrisinternational.com/ (Accessed 2 Dec 2002).

117 Folie M. [Memo to Randall Eiger]. 14 Oct 1992. Philip Morris. Bates No. 2022811113/1114. http://legacy.library.ucsf.edu/tid/ezf35e00

118 Tobacco Institute of Australia. Cigarette sales to young people. 1992. Philip Morris. Bates No. 2504067793/7796. http://legacy.library.ucsf.edu/tid/ qkw19e00

119 Gee L. Philip Morris retail focus. Jun 1998. Philip Morris. Bates No. 2063552738/2749. http://legacy.library.ucsf.edu/tid/sna42d00

120 Staunton D. [Letter to David Greenberg]. 24 Jun 1998. Philip Morris. Bates No. 2064831723/1724. http://legacy.library.ucsf.edu/tid/wtb63c00

121 Firestone M. Attribution. 27 Feb 1997. Philip Morris. Bates No. 2064820701. http://legacy.library.ucsf.edu/tid/rda63c00

122 Philip Morris Companies Inc. Policy statement on attribution. Feb 1997. Philip Morris. Bates No. 2064820702. http://legacy.library.ucsf.edu/tid/ sda63c00

123 Friedman MP. Australia-attribution. 29 Jun 1998. Philip Morris. Bates No. 2065349289/9290. http://legacy.library.ucsf.edu/tid/shu63c00

124 Greenberg D. I've got the power: attribution policy. 25 Jun 1998. Philip Morris. Bates No.2 065355555. http://legacy.library.ucsf.edu/tid/ fkw77d00

125 Staunton D. "I've got the power" program: attribution policy. 29 Jun 1998. Philip Morris. Bates No. 2065355552. http://legacy.library.ucsf.edu/tid/ $\mathrm{dkw} 77 \mathrm{~d} 00$

126 Friedman MP. Attribution. 30 June 1998. Philip Morris. Bates No. 2064831755. http://legacy.library.ucsf.edu/tid/aub63c00

127 Philip Morris Worldwide Regulatory Affairs. [Draft letter]. 30 Jun 1998. Philip Morris. Bates No. 2064831756. http://legacy.library.ucsf.edu/tid/ bub63c00

128 Friedman MP. [Fax cover sheet to Reg Hodgson]. 30 Jun 1998. Philip Morris. Bates No. 2064831752. http://legacy.library.ucsf.edu/tid/ ytb63c00

129 Philip Morris Worldwide Regulatory Affairs. [Draft letter]. 30 Jun 1998. Philip Morris. Bates No. 2064831753. http://legacy.library.ucsf.edu/tid/ ztb63c00

130 Donnelly K. Tobacco giant at arms length. The West Australian (Perth) 13 Jan 1999:16. 
131 Young A. Adviser defends education packs: tobacco cash 'not issue'. New Zealand Herald 26 Jan 1999. http://www.nzherald.co.nz/ storydisplay. $\mathrm{cfm}$ ?thesection $=$ news\&thesubsection $=$ \&storyID $=1757$ (Accessed 21 Jul 2003)

132 Jones C. Gude backs tobacco consultant: the Minister defends cigarette company's link to school kit. The Age (Melbourne, Vic) 26 Jan 1999:3.

133 Anon. Registration pamphlet for teacher workshops - I've Got the Power and Our Strengths. Adelaide, Melbourne, Sydney, Brisbane: Education Strategies, 2001.

134 Chapman S. Tobacco giant's antismoking course flops. BMJ 2001;323:1206.

135 Metherell M. Smoke giant offers lesson for schools. Sydney Morning Herald (Sydney, NSW) 21-22 Sep 2002:5.

136 Bible GC. Statement of Geoffrey C. Bible Philip Morris Companies Inc. before the Senate Commerce Committee. 24 Feb 1998. Philip Morris. Bates No. 2072043072/3108. http://legacy.library.ucsf.edu/tid/osy28d00

137 Philip Morris International. Meeting Philip Morris International's commitments on preventing youth smoking. 7 Apr 1998. Philip Morris. Bates No. 2065553273/3279. http://legacy.library.ucsf.edu/tid/xgk73c00

138 Gembler A. International tobacco marketing. 25 Feb 1998. Philip Morris. Bates No. 2065241442. http://legacy.library.ucsf.edu/tid/icc38d00

139 Philip Morris International. Marketing code. May 1998. Philip Morris. Bates No. 2065326393/6394. http://legacy.library.ucsf.edu/tid/pvo63c00

140 Daw A. Marketing code meeting-April 28th in Lausanne. 1 May 1998. Philip Morris. Bates No. 2065326391/6392. http:// legacy.library.ucsf.edu/tid/ovo63c00

141 Dangoor D. Marketing code. 28 Jul 1999. Philip Morris. Bates No. 2074761738/1739. http://legacy.library.ucsf.edu/tid/opp52c00

142 Hendrys PW. PMI marketing code and youth smoking prevention initiatives. 23 Sep 1999. Philip Morris. Bates No. 2072676451/6452. http:// legacy.library.ucsf.edu/tid/fgk26c00

143 Philip Morris International. Cigarette Marketing Code guidelines for implementation. 27 Jan 2000. Philip Morris. Bates No. 2072676459/6464. http://legacy.library.ucsf.edu/tid/ddh42c00

144 Cusato A, Dangoor D. Proposed revised PMI marketing code. 25 Apr 2000. Philip Morris. Bates No. 2078376534A. http://legacy.library.ucsf.edu/tid/ ysr72c00

145 Philip Morris International. Cigarette marketing code. 25 Apr 2000. Philip Morris. Bates No. 2078376535/6541. http://legacy.library.ucsf.edu/tid/ $\mathrm{xsr} 72 \mathrm{c00}$

146 Kush AO. Invitation-Youth Smoking Prevention Meeting, 27-28 July, Lausanne. 13 Jul 1999. Philip Morris. Bates No. 2070045517C. http:// legacy.library.ucsf.edu/tid/rxa38d00
147 No author London meeting: issues and next steps [draft]. 30 Mar 1998. Philip Morris. Bates No. 2072532472/2475. http:// legacy.library.ucsf.edu/tid/xma06c00

148 Gembler A. PMI Marketing philosophy and code. 22 Oct 1998. Philip Morris. Bates No. 2071353381/3382. http://legacy.library.ucsf.edu/tid/ qim08d00

149 Bodine MR. International youth access and marketing initiatives meeting. 13 Mar 1998. Philip Morris. Bates No. 2072664876. http:// legacy.library.ucsf.edu/tid/rsg42c00

150 No author. For discussion. 10 Mar 1998. Philip Morris. Bates No. 2072664877/4880. http://legacy.library.ucsf.edu/tid/qsg42c00

151 British American Tobacco, Compania Industrial de Tabacos SA, Grupo Iberoamericano de Fomento SA, et al. International tobacco products marketing standards. 2001. http://www. philipmorrisinternational.com/ global/downloads/sh/international_marketing_standards.pdf (Accessed 22 Jul 2003

152 Herzog B, Belpedio H. International tobacco marketing standards: new standards create consistent, responsible international marketing practices. Credit Suisse Equity Research/First Boston 2001. Last updated: 25 Sep 2001 http://www.ash.org.uk/html/advspo/pdfs/csfb.pdf (Accessed 25 Oct 2002)

153 British American Tobacco. Social report 2001/2002. London: British American Tobacco Corporation UK, 2002

154 Bible GC, Camilleri LC. Philip Morris Companies Inc. 2002 Annual Meeting of Stockholders April 25, 2002: remarks by Mr. Geoffrey C. Bible Chairman and Chief Executive Officer and Mr. Louis C. Camilleri Senior Vice President and Chief Financial Officer. Richmond, Va:Philip Morris Companies Inc, 2002. http://www.philipmorris.com/docs/investor rel/ 2002 AnnualReports/remarks.pdf (Accessed 29 Apr 2002)

155 British American Tobacco Australia Limited. A social report 2001-2002. Sydney: British American Tobacco Australia Limited, 2003.

156 Philip Morris Corporate Affairs (Worldwide). Corporate Affairs World Conference Issue Discussion Group summaries. 8 Nov 1995. Philip Morris. Bates No. 2047945425/5442. http://legacy.library.ucsf.edu/tid/ cdil8d00

157 Buettner M. Philip Morris shareholders overwhelmingly approve name change to Altria Group. Associated Press Newswires 26 Apr 2002 , Factiva.com News Service. (Accessed 22 Jul 2003)

158 Fairclough G. Study slams Philip Morris ads telling teens not to smoke: how a market researcher who dedicated years to cigarette sales came to create antismoking ads. Wall Street Journal (New York) 29 May 2002, Factiva.com News Service. (Accessed 22 Jul 2003) 